\title{
Zeszyty PRASOZNAWCZE
}

Kraków 2017, T. 60, nr 3 (231), s. 540-566

10.4467/22996362PZ.17.033.7330

www.ejournals.eu/Zeszyty-Prasoznawcze/

\section{BADANIA NAD KOMUNIKACJĄ MIĘDZYKULTUROWĄ: DOTYCHCZASOWE PARADYGMATY I PERSPEKTYWY BADAWCZE ${ }^{1}$}

\author{
MICHAŁ WILCZEWSKI
}

Instytut Komunikacji Specjalistycznej i Interkulturowej

Wydział Lingwistyki Stosowanej

Uniwersytet Warszawski

\begin{abstract}
ANNE-MARIE SØDERBERG
Department of Management, Society and Communication

Copenhagen Business School
\end{abstract}

\section{ABSTRACT \\ Intercultural communication studies: past paradigms and future research}

The article gives an overview of past and present intercultural communication studies based on a review of journal articles from the last decade. It also introduces a qualitative approach to studying cultural encounters and learning processes in organizations through narrative inquiry and narrative analysis. We propose that this narrative approach should be moved closer to the

${ }^{1}$ Artykuł jest finansowany z programu „Mobilność Plus” (IV edycja) Ministerstwa Nauki i Szkolnictwa Wyższego (umowa nr 1310/MOB/IV/2015/0) w ramach projektu badawczego pt. „Wpływ czynników specyficznych kulturowo na efektywność komunikacji interkulturowej w środowisku biznesowym".

Adres do korespondencji Anne-Marie Søderberg: Copenhagen Business School, Department of Management, Society and Communication; Dalgas Have, 2V.045, Frederiksberg (Dania); aso.msc@cbs.dk $\triangle$ Adres do korespondencji Michał Wilczewski: Uniwersytet Warszawski, Wydział Lingwistyki Stosowanej, Instytut Komunikacji Specjalistycznej i Interkulturowej; ul. Szturmowa 4, 02-678 Warszawa oraz Copenhagen Business School, Department of Management, Society and Communication; m.wilczewski@uw.edu.pl 
intercultural communication realm because it may serve as a tool for getting access to and achieving an understanding of how culturally diverse individuals tell about and reflect upon cultural encounters. The process of storytelling allows narrators to (a) re-experience and reflect on their (inter)cultural encounters, (b) give sense to those experiences, and (c) make sense of their current and previous psychological needs, perceptions of and expectations toward contacts with cultural Others. Analysis of stories about critical cultural encounters in a specific context allows the researcher to gain deeper insight into the process of intercultural communication whereby individuals make sense of challenging cultural experiences and construct their identity and potentially engage in cultural learning processes.

Keywords: intercultural communication, identity construction, cultural learning, narratives, organizational communication

\section{Wrowadzenie}

Procesy globalizacyjne, z jednej strony, dają przedsiębiorstwom nowe możliwości biznesowe i stymulują multikulturalizację społeczeństw i organizacji. Z drugiej strony już ponad dwie dekady temu Gary G. Hamilton (1994) przewidział, że globalizacja nie będzie zmierzać ani w kierunku konwergencji wartości, ani ku konwergencji kultur zachodnich, ale przyjął hipotezę, że różnorodność kulturowa (ang. cultural diversity) będzie stale obecna na horyzoncie poznawczym z racji tego, że wzorce cywilizacyjne są nieustannie rekonstruowane i włączane do systemów kulturowych. Tym samym, jakkolwiek rynki się globalizują, to społeczeństwa, gospodarki czy ideologie (włączając w to ideologie menedżerskie) pozostają kulturowo zróżnicowane, ponieważ organizacje są ustrukturyzowane i ufundowane na takich osiągnięciach cywilizacyjnych, jak dziedzictwo kulturowe czy systemy wartości, które wyznaczają kierunki rozwoju społeczeństw (Petrakis 2014, s. 146).

Porównawcze badania nad Azjatami, Amerykanami i mieszkańcami Europy Zachodniej pod kątem wpływu czynników kulturowych na zachowania i style komunikacyjne w wielonarodowym środowisku biznesowym (np. Ticehurst, Downs 1999; Phuong-Mai i in. 2005; Domurat i in. 2012) pokazują silną tendencję do klasyfikowania reprezentantów poszczególnych kultur według kryterium wymiarów kulturowych (Hofstede 1991, 2001) oraz do przewidywania na tej podstawie ich praktyk komunikacyjnych. Przez to badacze często zdają się ignorować takie czynniki, jak interakcja międzykulturowa czy kontekst zewnętrzny (polityczny, gospodarczy, społeczny, prawny itd.), w którym dana organizacja funkcjonuje, a przede wszystkim - indywidualne możliwości poznawcze jej członków.

Komunikacja międzykulturowa ${ }^{2}$ (ang. intercultural/cross-cultural communication) stała się dziedziną wiedzy skupiającą zainteresowania lingwistów, antropo-

2 „Komunikacja międzykulturowa” jest pojęciem szerokim, które jest zasadniczo rozumiane jako komunikacja między ludźmi należącymi do odmiennych kultur (Ratajczak 2006, s. 11). W obrębie komunikacji międzykulturowej można wyróżnić: komunikację poprzezkulturową (ang. cross- 
lingwistów, kulturologów, psychologów, badaczy poznania społecznego, ale przede wszystkim praktyków, którym bliskie są tematy z zakresu międzykulturowych kontaktów w międzynarodowych kontekstach biznesowych i organizacyjnych.

W artykule pokażemy, że podejmując tematy w obrębie komunikacji międzykulturowej, wielu badaczy zasadniczo skupia się na różnicach narodowych i etnicznych, przez co redukują zasięg pojęcia kultury do narodu. Również sposób podchodzenia do dynamiki procesów komunikacyjnych sugeruje, że konceptualnie podążają oni za tradycyjnym, pozytywistycznym myśleniem o kulturze, wyrażającym się w postrzeganiu jej przez pryzmat wymiarów kulturowych (zob. Triandis 1972; Hofstede 1980; Schwartz 1992; Smith i in. 2002; Trompenaars 1993; House i in. 2004). Myślenie to nierzadko narzuca ilościowe podejście do badań międzykulturowych i prowadzi do traktowania wymiarów kulturowych w kategoriach predyktorów zachowań w interakcjach międzykulturowych.

$\mathrm{W}$ odpowiedzi na te ograniczenia zaproponujemy, by badania zjawisk komunikacji międzykulturowej wzbogacić o studia $\mathrm{z}$ wykorzystaniem podejścia narracyjnego, które jest $\mathrm{z}$ powodzeniem stosowane $\mathrm{w}$ kontekstach organizacyjnych, zwłaszcza w badaniach nad współpracą w grupach międzykulturowych i nad komunikacją w organizacjach. Podejście narracyjne oferuje narzędzia dające dostęp do sposobów, w jakie uczestnicy komunikacji opowiadają o swoich międzykulturowych doświadczeniach, i do refleksji na ich temat - metoda narracyjna umożliwia ich głębsze zrozumienie.

Oprócz przybliżenia zakresu badań nad komunikacją międzykulturową przedstawimy rolę teorii komunikacji międzykulturowej oraz ukażemy zjawisko różnorodności kulturowej jako trend względnie świeży i pokazujący, że badacze międzykulturowi coraz częściej uświadamiają sobie, że w swoich badaniach mają do czynienia $\mathrm{z}$ wielością kultur, a nie z kulturami narodowymi, i że coraz więcej ludzi prezentuje różnorodność (dwu- $\mathrm{i}$ wielokulturowych) tożsamości aniżeli pojedynczą tożsamość etniczną czy narodową. Następnie, na podstawie metaanalizy Lily A. Arasaratnam (2015), zostaną przedstawione główne zagadnienia, które od ponad dekady przyciągają uwagę badaczy komunikacji międzykulturowej. Był to czas dynamicznych zjawisk społecznych, kulturowych i gospodarczych, takich jak migracja, ekspatriacja i współpraca w zespołach wirtualnych, które przykuły uwagę badaczy i doprowadziły do wyłonienia się nowych tematów, m.in. adaptacji kulturowej czy rozwoju kompetencji międzykulturowych i globalnego przywództwa (Gertsen i in. 2012). W końcu w odpowiedzi na dominującą tendencję do postrzegania komunikacji międzykulturowej w kategoriach procesu angażującego kultury narodowe, a tym samym często prowadzącego do problemów i barier

-cultural communication), komunikację pomiędzykulturową (ang. intercultural communication) i komunikację międzynarodową (international communication) (Mikułowski Pomorski 2007, s. 73). Używając w artykule terminu komunikacja międzykulturowa, będziemy mieli na myśli interakcję komunikacyjną - albo praktyki komunikacyjne w interakcji (Piller 2007, s. 208) - między osobami z różnym zapleczem kulturowym, co najbliżej odpowiada pojęciu „komunikacji pomiędzykulturowej” u Jerzego Mikułowskiego Pomorskiego. 
komunikacyjnych w zglobalizowanym biznesie (zob. np. Ferraro 2002), zaproponujemy narracyjne podejście do badania doświadczeń (między)kulturowych oraz procesu kulturowego uczenia się. Pokażemy, że analiza narracyjna, która do tej pory była skutecznym narzędziem badania zjawisk międzykulturowych w kontekstach organizacyjnych, może się równie skutecznie sprawdzić w badaniu kontaktów międzykulturowych. Jej zalety dają badaczom szanse pogłębiania zrozumienia, w jaki sposób ludzie o różnym zapleczu kulturowym współpracują ze sobą, jak zdają sprawę z własnych doświadczeń międzykulturowych w procesie opowiadania o nich, jak nabywają kompetencji międzykulturowej i jak konstruują tożsamość (kulturową) własną i innych.

\section{Komunikacja międzykulturowa}

Różnorodność kulturowa stawia nowe wyzwania dla badań (między)kulturowych i wymaga zredefiniowania takich pojęć, jak „kultura” czy „tożsamość kulturowa”. Pojęć tych nie da się już postrzegać homogenicznie i synonimicznie z „narodem” czy „tożsamością narodową”. Kulturę rozumiemy - zgodnie z perspektywą interpretacyjną $\mathrm{i}$ konstruktywistyczną, która w centrum zainteresowania stawia sposoby społecznego konstruowania zjawisk w określonych kontekstach, z naciskiem na determinującą rolę interakcji w tym konstruowaniu (por. Holstein, Gubrium 2008, s. 375; Roulston 2010, s. 218) - jako nieustanną (re)konstrukcję i (re)negocjację znaczeń (Ganesh, Holmes 2011), jako złożone źródło znaczeń, które nie są stałe, a do których ludzie odnoszą się, by nadać sens swoim doświadczeniom i by je zrozumieć. Z kolei na tożsamość kulturową (grupową, kolektywną), przejawiającą się w poczuciu przynależności do grupy, składają się czynniki warunkujące ludzkie zachowania. Czynniki te są związane z kulturą regionalną, organizacyjną, pokoleniową, religijną, płciową itd. (Sackmann, Phillips 2004).

Podstawowym celem badań międzykulturowych jest poznawanie i wyjaśnianie natury kontaktów między osobami z różnych kultur. Ponieważ komunikację rozumiemy jako proces tworzenia znaczeń, na komunikację międzykulturową patrzymy jako na proces konstruowania znaczeń w drodze interakcji między osobami z różnym zapleczem kulturowym, o kulturowo różnych doświadczeniach, różnie postrzegającymi świat i prezentującymi różne zachowania w określonych kontekstach. Właśnie te różnice determinują specyficzną atrybucję znaczeń (por. Gudykunst, 1997; Carbaugh 1990), która ujawnia się w międzykulturowej interakcji, gdy różne językowe i kulturowe konwencje wchodzą ze sobą w kontakt (por. ten Thije, Maier 2012).

Z kolei efektywna interakcja międzykulturowa umożliwia uczestnikom komunikacji konstruowanie zrozumiałych znaczeń na tyle, na ile interlokutorzy są świadomi własnych i cudzych potrzeb, stanów mentalnych i różnic w tożsamości osobistej, kulturowej, religijnej, narodowej, płciowej, społecznej, zawodowej itd. (W literaturze pojawia się nawet pojęcie ,międzykulturowego rozmówcy” [ang. 
intercultural speaker; Byram 2009], który umiejętnie radzi sobie z rozwiązywaniem konfliktów, jest otwarty na innych ludzi, ma świadomość wyznawanych przez siebie wartości, jak również wartości ważnych dla jego rozmówcy). Natomiast samo tworzenie znaczeń i dzielenie się nimi - czy raczej ich negocjowanie z innymi ludźmi - odbywa się przy użyciu kulturowo zależnych symboli (komunikowanych werbalnie i niewerbalnie), osadzonych w specyficznych ramach odniesienia, takich jak postrzeganie czasu i przestrzeni, przekonania, wartości, społeczne normy zachowań i style komunikacyjne.

\section{Teorie komunikacji międzykulturowej}

Celem projektowania, rozwijania, testowania i rekonceptualizacji teorii międzykulturowych jest ,poszukiwanie procesów normalizacyjnych, które pomogłyby zmniejszyć dysonans i niepewność pojawiające się wówczas, gdy kultura dominująca ściera się z innymi kulturami” (Dougherty i in. 2010, s. 164; tłum. M.W.). To kulturowe ścieranie się jest typowe dla każdego rodzaju interakcji i powodowane jest kulturowo zależnymi zjawiskami poznawczymi, językowymi, psychologicznymi i społecznymi, jak np. zarządzaniem tożsamością, relacjami interpersonalnymi, procesami negocjacji i podejmowania decyzji, stylami myślenia (np. symboliczne, indywidualne vs. kolektywne), stylami interakcji, skryptami kulturowymi itd. Zatem cel teorii komunikacji międzykulturowej nie ogranicza się jedynie do identyfikacji potencjalnych barier i przeszkód w kontaktach międzykulturowych, a następnie sugerowania strategii zapobiegania im (funkcja preskryptywna), ale przede wszystkim powinien polegać na łączeniu grup różnorodnych kulturowo i wskazywaniu możliwych obszarów współpracy, na możliwych korzyściach płynących z różnorodności kulturowej, czyli - ogólnie rzecz biorąc - na międzykulturowym dialogu.

W swoim przeglądzie teorii międzykulturowych William B. Gudykunst (2005) sklasyfikował teorie zorientowane na osiąganie skutecznych wyników, akomodację i adaptację, zarządzanie tożsamością, przystosowanie do nowego otoczenia kulturowego. Wśród tych podejść można wyróżnić teorie, które:

a) łączą kulturę i komunikację: np. teoria konstruktywistyczna (ang. constructivist theory; Applegate, Sypher 1988), skoordynowane zarządzanie znaczeniem (ang. coordinated management of meaning; Cronen i in. 1988), teoria kodów językowych (ang. speech code theory; Philipsen i in. 2005);

b) wyjaśniają kulturowe różnice w procesie komunikacji na poziomie indywidualnym i kulturowym: teoria negocjowania twarzy (ang. face-negotiation theory; Ting-Toomey 2005), teoria ograniczeń konwersacyjnych (ang. conversational constraints theory; Min-Sun Kim 1995) czy teoria oczekiwań naruszenia (ang. expectancy violations theory; Burgoon 1995);

c) skupiają się na efektywnej komunikacji i grupowym podejmowaniu decyzji: teoria konwergencji (ang. convergence theory; Kincaid 1987), teoria kontroli niepokoju/niepewności (ang. anxiety/uncertainty management 
theory; Gudykunst 1995), teoria efektywnego podejmowania decyzji (ang. effective decision-making theory; Oetzel 1995) czy integracyjna teoria komunikacji (ang. integrative communication theory; Young Yun Kim 2001).

Od czasu przeglądu W.B. Gudykunsta ukonstytuowała się nowa kategoria obejmująca modele akulturacji ${ }^{3}, \mathrm{~m}$.in. rozszerzony model względnej akulturacji (ang. relative acculturation extended model; Navas i in. 2005), interakcyjny model akulturacji (ang. interactive acculturation model; Komisarof 2009) czy wielowymiarowy model akulturacji oparty na różnicach indywidualnych (ang. multi-dimensional individual difference acculturation model; Safdar i in. 2012).

Ostatnia dekada była czasem wprowadzania nowych modeli, testowania nowych i dotychczasowych instrumentów badawczych, a także nakreślania i udoskonalania konceptualnych ram badań komunikacji międzykulturowej (zob. Arasaratnam 2015). Na przykład Sacheen K. Mobley i Siobhan E. Smith (2010) wykazali wysoką relewancję teorii konwergencji językowej i dywergencji znaczeń (ang. theory of language convergence/meaning divergence; Dougherty i in. 2009, 2010) dla badań komunikacji międzykulturowej. Konwergencja językowa (stosowanie powszechnych etykiet językowych) pociąga za sobą semantyczną dywergencję, a tym samym powoduje wzrost poziomu lęku i braku zaufania. Następnie przetestowano m.in. teorię efektywnej międzykulturowej komunikacji zadaniowej w grupach (ang. effective intercultural workgroup communication theory; Oetzel i in. 2012), model wrażliwości międzykulturowej (ang. model of intercultural sensitivity; Tamam 2010), unikanie niepewności w negocjowaniu twarzy (ang. uncertainty avoidance and facework; wymiaru kulturowego Geerta Hofstedego; Merkin 2006), rozszerzony model względnej akulturacji (ang. relative acculturation extended model; Navas i in. 2005), interakcyjny model akulturacji (ang. interactive acculturation model; Komisarof 2009) czy ww. wielowymiarowy model akulturacji (Safdar i in. 2012).

Nie wdając się w szczegóły wymienionych wyżej teorii, co zresztą byłoby zadaniem karkołomnym ze względu na ich wielość, w przedostatniej części artykułu (Podejście narracyjne do badań nad [komunikacyjnymi] doświadczeniami międzykulturowymi) zaproponujemy alternatywne podejście do studiowania komunikacji międzykulturowej, które wywodzi się z narratologii i zyskuje coraz większą popularność wśród mających doświadczenie w badaniach komunikacyjnych badaczy międzynarodowego biznesu.

\footnotetext{
3 „Akulturacja” (albo też „kulturowa asymilacja”, Gordon 1971) to proces kulturowego uczenia się i dopasowania (behawioralnego) osób i grup w rezultacie kontaktu z nowym środowiskiem kulturowym (Berry 1980; Padilla 1980). Akulturacja jest procesem poznawczym i emocjonalnym, polegającym na doświadczeniu specyficznych aspektów kultury odmiennej, zrozumieniu ich oraz zaadaptowaniu do stopnia, który powoduje u człowieka zmiany w jego tożsamości kulturowej, wartościach, zachowaniach, sposobie postrzegania rzeczywistości, postawach względem członków odmiennej grupy kulturowej itd. (por. Miller i in. 2006).
} 


\section{Różnorodność kulturowa w komunikacji w organizacjach-zmiana paradygmatu}

Badanie różnorodności kulturowej jest jednym z bardziej aktualnych trendów w badaniach nad współpracą $\mathrm{w}$ grupach wielokulturowych. Ze względu na zalety i wady, jakie różnorodność kulturowa niesie w kontekście współpracy w biznesie, w literaturze ukuto pojęcie ,paradoksu kulturowego” (ang. cultural paradox), polegającego na tym, że ,różnorodność kulturowa jest zarówno źródłem stymulacji, kreatywności, nagrody, jak i źródłem potencjalnych konfliktów wartości, zachowań, praktyk i przekonań" (Vangen, Winchester 2014, s. 702; tłum. M.W.).

$\mathrm{Z}$ jednej strony prace, które wpisują się w tradycyjne podejście do różnorodności kulturowej (tzn. takie, w których pole widzenia badacza ogranicza się do barier w komunikacji międzykulturowej), rysują obraz różnorodności kulturowej jako źródła konfliktów wartości, zachowań, praktyk i przekonań. Na przykład Rajesh Kumar i Kofi O. Nti (2004) wskazują, że wartości narodowe utrudniają budowanie strategicznych sojuszy międzynarodowych, gdyż są źródłem:

a) konfliktów interpretacyjnych - wynikających z błędnego rozpoznania problemu, przez co takie konflikty prowadzą do dywergencji znaczeń, do niepowodzenia interpretacyjnego powodowanego różnicami kulturowymi;

b) konfliktów atrybucyjnych - wynikających z „błędu atrybucji” (Ross 1977) i wyrażających się w wyjaśnianiu ludzkich zachowań przez pryzmat przyczynowych związków dyspozycyjnych (wewnętrznych) i sytuacyjnych ${ }^{4}$, a także

c) konfliktów behawioralnych - wynikających z behawioralnej niekompatybilności pomiędzy partnerami, np. gdy mają różne oczekiwania w stosunku do siebie nawzajem i do potencjalnej współpracy z sobą.

Poza tym mówi się o negatywnym wpływie różnic kulturowych w kontekście fuzji, przejęć i tworzenia spółek joint ventures. Na przykład Frédéric Prevot i Pierre-Xavier Meschi (2006), analizując przypadek francusko-brazylijskiej spółki joint venture, zauważyli, że brak zrozumienia istoty różnic kulturowych wśród menedżerów może prowadzić do kulturowego zderzenia i konfliktu, co skutkuje ich rotacją i trudnościami w realizowaniu celów operacyjnych.

Z drugiej strony coraz więcej badaczy wskazuje, że różnorodność kulturowa może być również postrzegana jako źródło pobudzania kreatywności, a nawet jako forma nagrody (Shenkar, Zeira 1992; Child, Faulkner 1998; Park, Ungson 1997; Sheer, Chen 2003; Kumar, Nti 2004; van Marrewijk 2004; Bird, Osland

\footnotetext{
${ }^{4}$ Na przykład Markus i in. (1997) wykazali, że członkowie kultur zachodnich, którzy cenią sobie dominację nad naturą - w przeciwieństwie do reprezentantów kultur wschodnich, którzy cenią sobie harmonię z naturą (Kluckhohn, Strodtbeck 1961; Nisbett i in. 2001) - mają skłonność do używania atrybucji dyspozycyjnych (wewnętrznych); przypisywanie przyczynowości jednostkom jest kluczowe, bo napędza i kieruje ich zachowaniem. Natomiast ci drudzy dużo częściej akcentują współzależność jednostki i grupy, przy czym przypisywanie przyczynowości jednostce nie jest ani możliwe, ani pożądane (Kumar, Nti 2004, s. 351).
} 
2006; Prevot, Meschi 2006), podczas gdy kulturowe podobieństwo partnerów może ograniczać możliwości współpracy (Vangen, Winchester 2014).

Ponadto zgodnie z koncepcją Pozytywnego Potencjału Organizacji (zob. m.in. Cameron i in. 2003; Kalinowska-Andrian 2006; Rozkwitalska 2011) oraz psychologii zarządzania (Stevens i in. 2008) praca w zespołach wielokulturowych rozwija kapitał społeczny i relacje interpersonalne, a także pobudza wzrost kreatywności wśród członków takich zespołów, co jest nieodzowne w rozwijaniu kompetencji międzykulturowej. Poprzednie badania pokazują explicite, że różnorodność sposobów myślenia eliminuje efekt myślenia grupowego i że interakcje międzykulturowe między ludźmi prezentującymi różne doświadczenia, modele percepcji, myślenia oraz podejścia do rozwiązywania problemów poszerzają możliwości rozwiązywania problemów (Stahl i in. 2010, s. 439-447). Nie dziwi więc fakt, że niektórzy badacze skupiają szczególną uwagę na osobach dwu- i wielokulturowych, pełniących funkcję pracowników przekraczających granice organizacji (ang. boundary spanners) czy „budowniczych mostów” (Fitzsimmons i in. 2011; Lücke i in. 2014).

Co więcej, różnorodność kulturowa może prowadzić do zwiększenia satysfakcji z pracy, rozwoju osobistego i zawodowego, i być szansą na zdobywanie nowych doświadczeń, wiedzy, być formą przygody itd. (Suutari, Mäkelä 2007; Stahl i in. 2010; Rozkwitalska 2011), a samo komunikowanie się w zespołach zróżnicowanych kulturowo może prowadzić do zaspokojenia u pracowników psychologicznej potrzeby szacunku (Wilczewski 2015; Gut i in. 2017; Wilczewski $\mathrm{i}$ in. 2017). Z kolei płynąca $\mathrm{z}$ interakcji międzykulturowych różnorodność doświadczeń ma poprawiać komunikację (Stahl i in. 2010) i funkcjonowanie procesu podejmowania decyzji dzięki zrozumieniu specyfiki lokalnych warunków rynkowych (McFarlin, Sweeney 2006). W końcu ta różnorodność stymuluje rozwój osobisty i zawodowy przez zdobywanie nowej wiedzy oraz podejmowanie wyzwań pojawiających się w środowisku międzykulturowym.

Ostatnimi czasy obserwuje się trend postrzegania różnorodności kulturowej w kategoriach kapitału, a nie źródeł barier i trudności, np. komunikacyjnych, co można thumaczyć zmianą sposobu myślenia o kulturze. Mowa tu o zmianie paradygmatu myślenia o komunikacji międzykulturowej, która angażuje nie tyle kultury narodowe, ile raczej wielokulturowość (Sackmann, Phillips 2004), bogactwo kultur regionalnych, organizacyjnych, zawodowych, pokoleniowych, religijnych, związanych z płcią itd. Prezentując tradycyjne podejście do badań w zakresie zarządzania międzykulturowego czy międzynarodowego oraz innych zjawisk organizacyjnych (np. komunikacji, negocjacji, podejmowania decyzji), badacze zazwyczaj skupiają się na odkrywaniu uniwersalnych wymiarów kulturowych (zob. Triandis 1972; Hofstede 1980; Schwartz 1992; Smith i in. 2002; Trompenaars 1993; House i in. 2004), które pozwoliłyby stworzyć w drodze badań ankietowych kulturową mapę świata. Jedną z motywacji do tworzenia takich map jest chęć praktycznej pomocy członkom organizacji w zrozumieniu kontekstów kulturowych, co ma się przekładać na zwiększenie efektywności ich pracy w środowisku międzynarodowym. 
Jednak, jak zauważają Sonja A. Sackmann i Margaret E. Phillips (2004, s. 372), identyfikacja uniwersalnych kategorii/ wymiarów kulturowych i umieszczanie ich na skalach psychometrycznych, mierzących te wymiary na poziomie narodowym (a nie indywidualnym), prowadzą do pozytywistycznej koncepcji jednostki, całkowicie identyfikującej się z narodem, do którego należy (jest jego reprezentantem). Koncepcja ta zakłada tym samym zrównanie w obrębie konkretnego wymiaru wyniku dla narodu $\mathrm{z}$ wynikiem indywidualnym. Niestety w praktyce nie jest to wykonalne, bo wyniki na poziomie indywidualnym i narodowym będą się różnić. Jakkolwiek pomiary na poziomie narodowym mogą służyć jako punkt odniesienia do badań nad komunikacją międzykulturową, to nie da się ich postrzegać w kategoriach predykatorów potencjalnych postaw, zachowań, wyznawanych wartości itd., manifestowanych w kontaktach międzykulturowych. Natomiast perspektywa wielości kultur zrywa z postrzeganiem kultury narodowej jako źródła identyfikacji jednostki, a raczej dostrzega, że jednostki mogą się identyfikować z różnymi grupami kulturowymi, być członkami kilku z nich jednocześnie (co wykazał np. M. Pratt 1998).

\section{Komunikacja międzykulturowa: zagadnienia dominujące}

Wzmożona mobilność geograficzna, większy i łatwiejszy dostęp do technologii informacyjnych i komunikacyjnych (znacznie ułatwiających komunikację i współpracę międzykulturową), a także wzrost migracji wpłynęły na skokowy wzrost popularności badań nad istotą i efektywnością kontaktów międzykulturowych. Warto w tym kontekście przywołać metaanalizę tematyczną L.A. Arasaratnam (2015), która dokonała przeglądu ponad sześciuset oryginalnych prac naukowych opublikowanych w latach 2003-2013 w trzech znaczących czasopismach z dziedziny komunikacji międzykulturowej: Journal of International and Intercultural Communication, Journal of Intercultural Communication Research oraz International Journal of Intercultural Relations. W rezultacie autorce udało się wyodrębnić osiem głównych zagadnień (zob. tabela 1):

1) zagadnienie „tożsamości” oscyluje wokół problemów migracji oraz zwiększonej mobilności globalnej; badania nad tożsamością odkrywają wpływ migracji na konstruowanie tożsamości indywidualnej i kolektywnej, a zakres całego zagadnienia obejmuje tematy poświęcone konstytuowaniu „tożsamości międzykulturowej”, czyli „otwartej, adaptacyjnej i transformacyjnej orientacji «ja - inny»" (Young Yun Kim 2008, s. 364; thum. M.W.);

2) ,akulturacja i migracja globalna” jest najszerszą kategorią badań nad postrzeganiem imigrantów i różnych aspektów wielokulturowości;

3) „dynamika procesu komunikacji” obejmuje badania nad zarządzaniem konfliktami i różnorodnością kulturową $\mathrm{w}$ kontekstach profesjonalnych i nieprofesjonalnych; 
4) studia nad „kompetencją międzykulturową” są poświęcone specyficznym modelom kompetencji międzykulturowej i badaniu wpływu kontaktów międzykulturowych na rozwój tej kompetencji;

5) konceptualizowanie, rozwijanie i testowanie teorii komunikacji międzykulturowej oraz prezentowanie wyników ich aplikacji w nowych kontekstach (to zagadnienie nie zostało ujęte $\mathrm{w}$ tabeli $1 \mathrm{z}$ racji wcześniejszego omówienia teorii komunikacji międzykulturowej; poza tym uważamy, że zagadnienie stricte teoretyczne i metodologiczne nie przystaje do pozostałych kategorii, które są konceptualne i empiryczne);

6) kategoria poświęcona „percepcji, stereotypom i dyskryminacji” obejmuje studia nad postawami i zachowaniami wynikającymi ze stereotypowego postrzegania członków kultury „obcej”;

7) „różnice międzykulturowe” to szerokie zagadnienie skupiające badania porównawcze, pogłębiające wiedzę nad komunikacją międzykulturową;

8) w zakres „edukacji międzykulturowej” wchodzą studia prezentujące znaczenie szkoleń międzykulturowych m.in. w procesie kulturowego uczenia się.

Po pierwsze, powyższa analiza podejmowanych tematów w obrębie komunikacji międzykulturowej jasno pokazuje, że główne zainteresowania badaczy na przestrzeni ostatniej dekady oscylują wokół problemów związanych z migracją, co nie dziwi w świetle wzmożonej globalizacji i migracji, zwłaszcza w kontekście europejskim. Tym samym można zaobserwować redukcjonizm w zakresie obiektu badań ze względu na ignorowanie innych różnic kulturowych niż różnice narodowe i etniczne (kultura jest ewidentnie zredukowana do narodu).

Po drugie, obserwując sposób, w jaki badacze podchodzą do dynamiki procesów komunikacyjnych, można wywnioskować, że konceptualnie podążają oni za tradycyjnym, pozytywistycznym myśleniem o kulturze, wyrażającym się w postrzeganiu jej przez pryzmat wymiarów kultury, przez rozpatrywanie takich czynników, jak męskość, kolektywizm, konstruowanie ,ja” niezależnie vs. współzależnie i inne czynniki psychokulturowe w kategoriach determinantów efektywnej komunikacji między ludźmi zróżnicowanymi kulturowo albo w kategoriach predyktorów konfliktów komunikacyjnych. Tym samym badacze znów zdają się wpadać w pułapkę redukcjonizmu z racji ograniczania poziomu badania do narodu (pomijając jednostkę), zaś metody - do kwantyfikacji, co szczególnie widać w badaniach nad różnicami kulturowymi. Naturalnie nie jest to regułą dla wszystkich badaczy (komunikacyjnych) doświadczeń międzykulturowych, ale trzeba podkreślić dominujący trend kwantytatywny w wiodących czasopismach z zakresu komunikacji międzykulturowej w porównaniu z podejściami wykorzystującymi metody jakościowe i skupiającymi się na jednostkach (pomijając tym samym poziom narodowy, co notabene jest uzasadnione z punktu widzenia podejścia konstruktywistycznego, zgodnie z którym kultura nie jest tożsama z narodem).

Odpowiadając na powyższe ograniczenia, proponujemy, by badania zjawisk komunikacji międzykulturowej wzbogacić o studia z wykorzystaniem podejścia narracyjnego. Narracje dotyczące doświadczeń kulturowych leżą w centrum ak- 


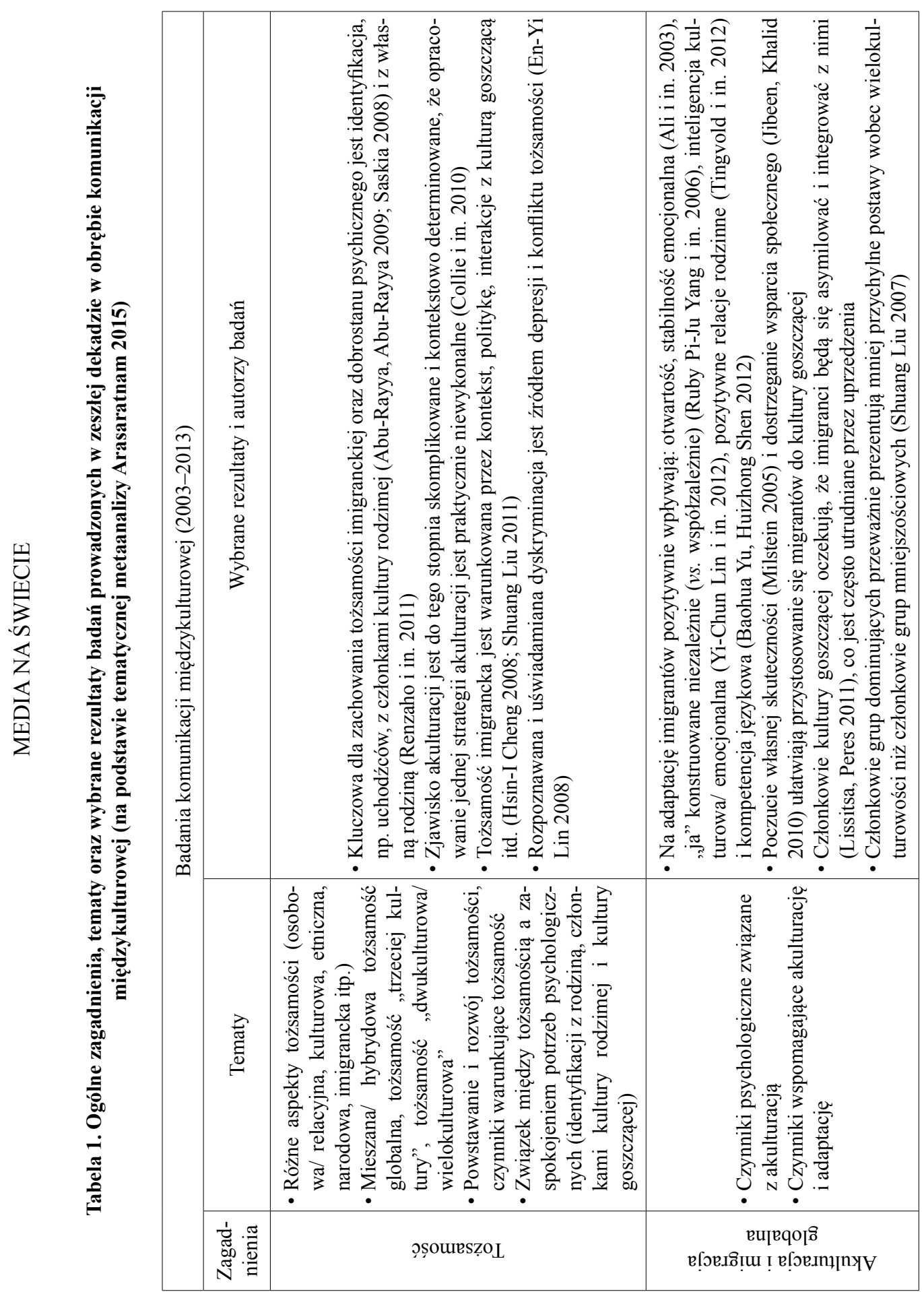




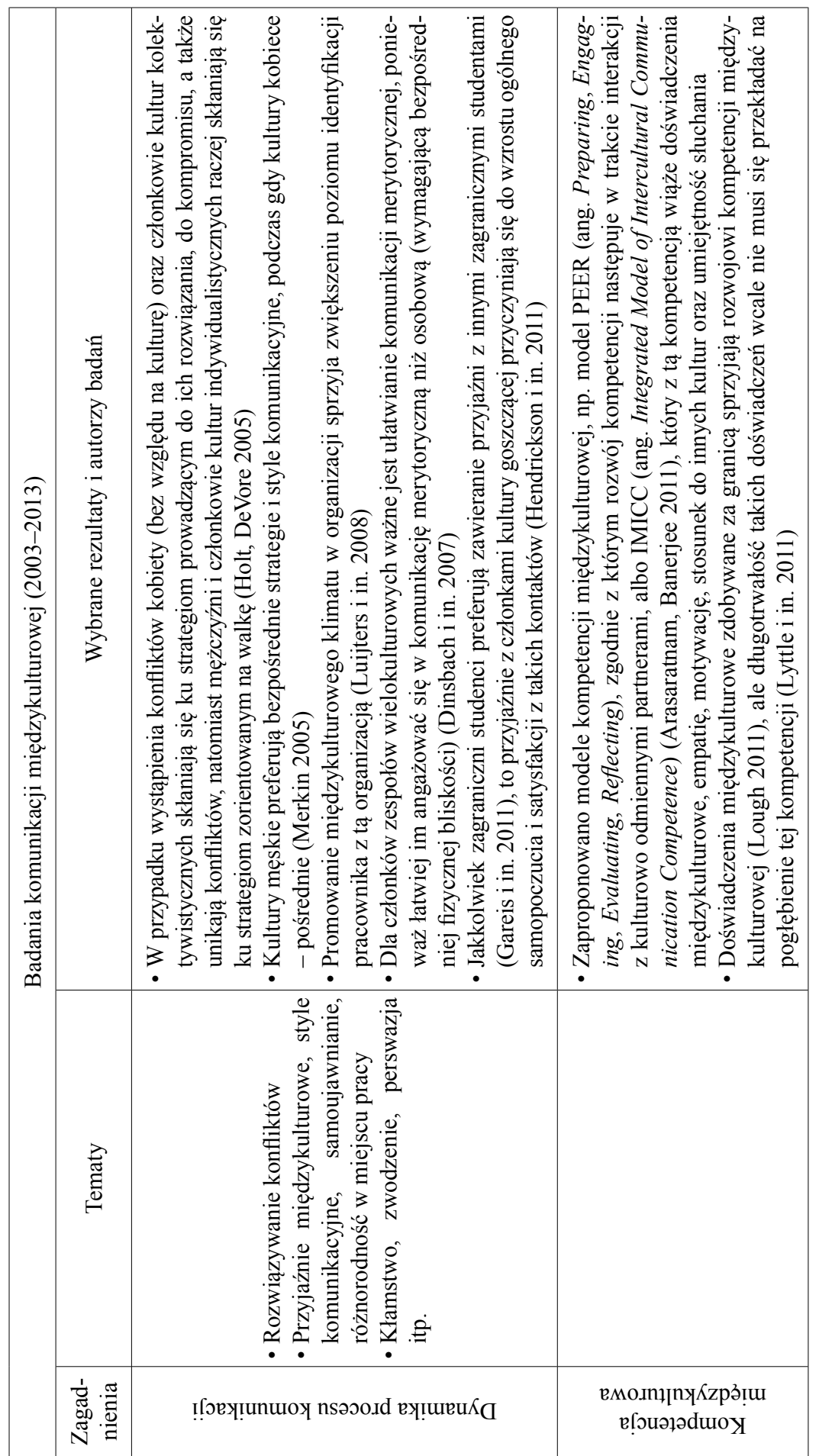




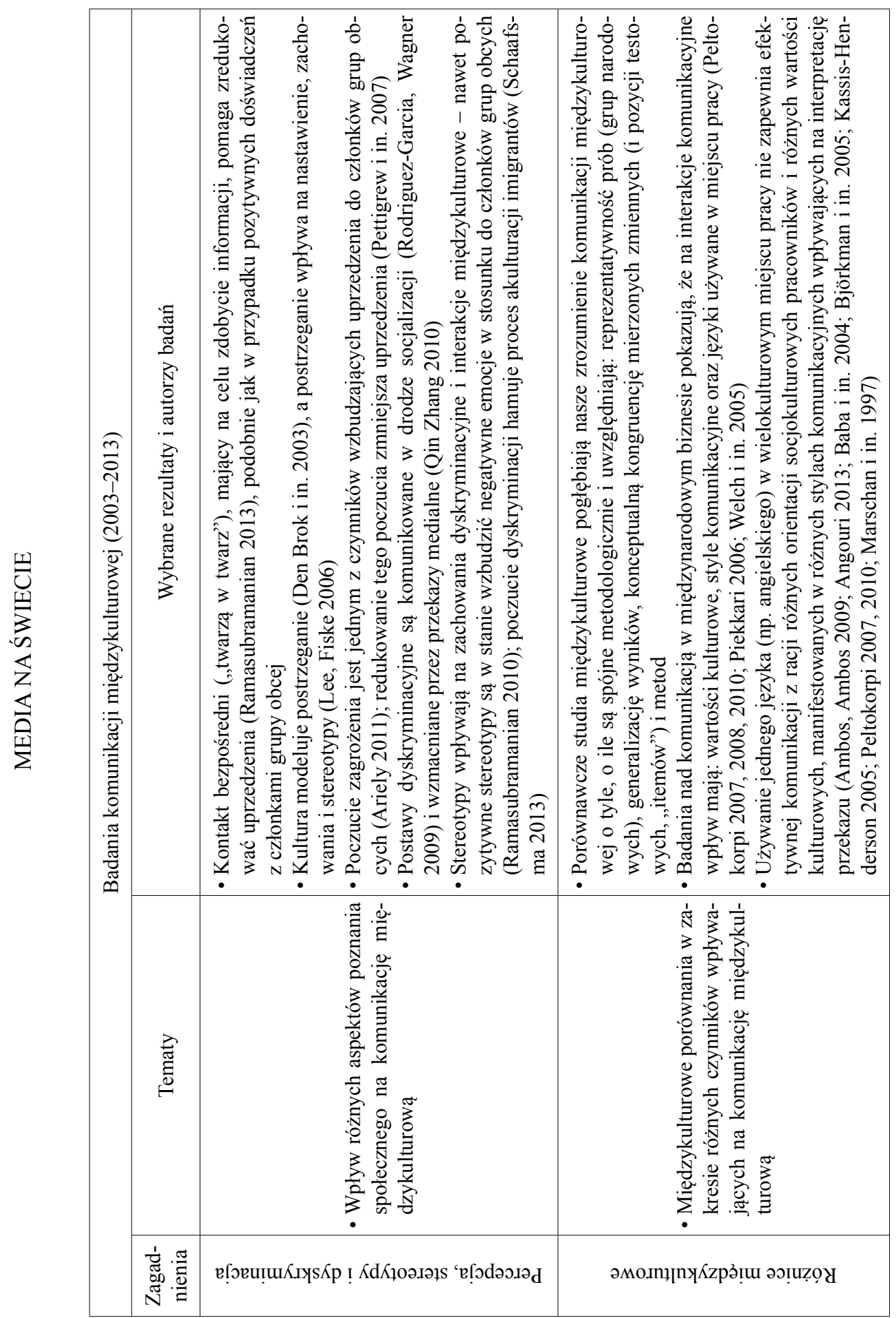




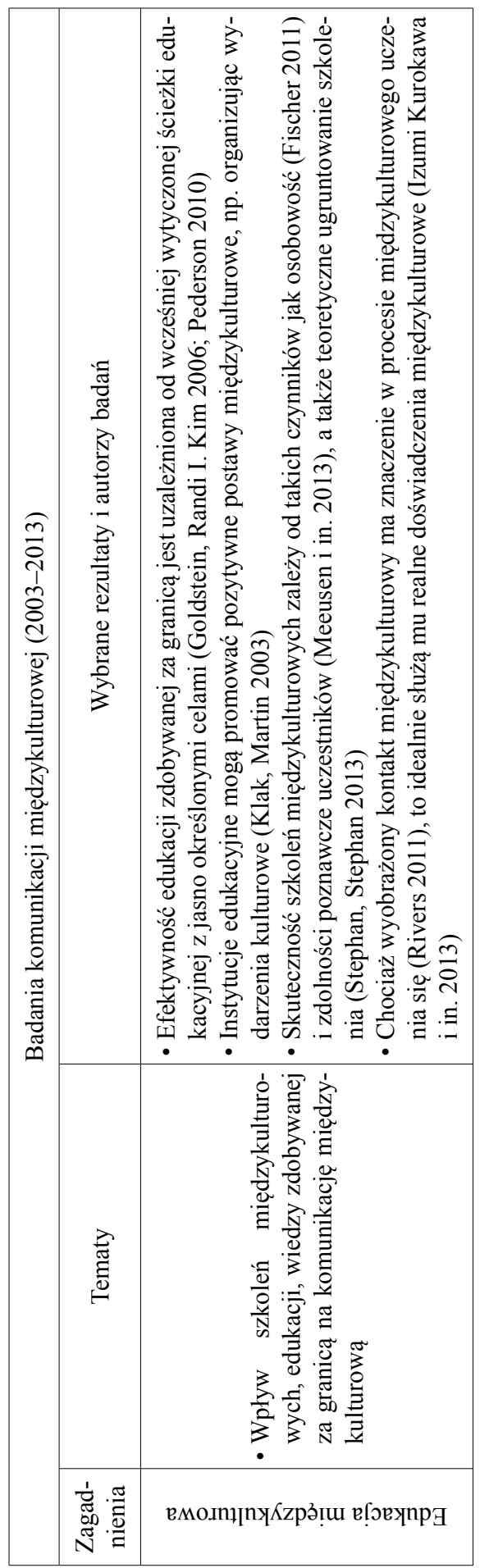


tywności uświadamiania, zdawania sobie sprawy z otaczającej rzeczywistości i nadawania wydarzeniom znaczenia. Co więcej, są „ośrodkami społecznej konstrukcji wielu tożsamości” (Søderberg 2006, s. 403; tłum. M.W.) w kontekście doświadczeń międzykulturowych. Z kolei analiza narracyjna, umożliwiająca dostęp do opowieści na temat komunikacyjnych i kulturowych doświadczeń, może być narzędziem pogłębiania zrozumienia refleksji wynikającej z tych doświadczeń, co pozwala badaczowi spojrzeć na proces komunikacji międzykulturowej z perspektywy indywidualnej - z perspektywy samego uczestnika komunikacji.

Podejście narracyjne wykazuje obiecujący potencjał w badaniach nad komunikacją międzykulturową z racji jego dotychczasowego, efektywnego zastosowania w kontekstach organizacyjnych, zwłaszcza w badaniach nad współpracą w grupach międzykulturowych i nad komunikacją w organizacjach. Natomiast metoda narracyjna jest pełnoprawną metodą jakościową, oferującą konceptualny i analityczny repertuar środków umożliwiających wgląd w ludzkie doświadczenia interakcyjne, który trudno uzyskać przy zastosowaniu innych narzędzi (np. kwestionariusza ankiety czy nawet wywiadu).

\section{Podejście narracyjne do badań nad (komunikacyjnymi) doświadczeniami międzykulturowymi}

Wraz ze zwrotem lingwistycznym - przy stosowaniu podejścia narracyjnego do badań nad zjawiskami organizacyjnymi - komunikację przestano traktować z perspektywy funkcjonalistycznej jako przepływ informacji, a zaczęto o niej myśleć konstruktywistycznie, jako o procesie tworzenia znaczeń i nadawania sensu otaczającej człowieka rzeczywistości. Narrację w tym procesie postrzega się jako przesiewający komunikację filtr, przez co narracja współtworzy znaczenia, kształtuje, modeluje je w akcie opowiadania (ang. storytelling). To współtworzenie odbywa się w socjohistorycznym kontekście opowiadanych wydarzeń, tj. w specyficznym momencie, gdy narrator opowiada historię konkretnemu słuchaczowi, a także z uwzględnieniem stanu psychologicznego uczestników komunikacji, ich nastroju, emocji, potrzeb, oczekiwań itd.

Ontologicznie rzecz ujmując, narracje są ,dyskretnymi, dającymi się oderwać od rzeczywistości dyskursywnej jednostkami [znaczenia] o jasno określonym początku i końcu" (Riessman 1993, s. 17; thum. M.W.), o strukturze chronologicznej, tematycznej i wynikowej (Steuer, Wood 2008, s. 575). Tego rodzaju struktury semantyczne służą organizowaniu ludzkich działań i otaczających człowieka zjawisk, przez co narracje nadają znaczenie tym działaniom i zjawiskom z unikalnej perspektywy konkretnego człowieka (narratora) (Polkinghorne 1988, s. 18).

Wielu badaczy, np. Barbara Czarniawska i Pasquale Gagliardi (2003), Anne-Marie Søderberg (2006) czy Karl E. Weick i in. (2005), podkreśla organizacyjną funkcję narracji, która jest niezmiernie istotna w kontekstach międzykulturowych, a zwłaszcza w organizacjach wielokulturowych, gdzie codzienna współpraca od- 
bywa się między pracownikami zróżnicowanymi kulturowo. Narracje tworzą organizacje i determinują procesy nadawania sensu i znaczeń zjawiskom organizacyjnym.

W kontekstach międzykulturowych narracje wpływają na to, w jaki sposób uczestnicy komunikacji rozumieją „,rzeczywistości, które przeżywają swoimi opowieściami” (Musacchio Adorisio 2015, s. 80), a tym samym pełnią funkcję poznawczą, semantyczną i wyjaśniającą. Jerome Bruner jasno stwierdza, że gdyby nie narracje, ludzie nie potrafiliby zdać sobie sprawy ze swojej najbardziej podstawowej potrzeby społecznej i kulturowej, tj. z komunikacji: ,,[narracja] jest warunkiem wstępnym dla kolektywnego życia w kulturze. Wątpię, żeby takie kolektywne życie było możliwe, gdyby nie ludzka zdolność organizowania i komunikowania doświadczenia w narracyjnej formie" (Bruner 2002, s. 16).

Podejście narracyjne okazuje się efektywnym narzędziem do badania międzykulturowych zjawisk w kontekstach organizacyjnych. Na przykład Martine C. Gertsen i Anne-Marie Søderberg $(2010,2011)$ wykazali możliwości zastosowania metody narracyjnej w analizie doświadczeń kulturowych ekspatów na przykładzie duńskich menedżerów pracujących w Chinach. Autorzy pokazali, że metoda pozwala badać procesy kulturowego uczenia się oraz rozwój kompetencji międzykulturowej i kulturowej inteligencji (Plum i in. 2008; Thomas i in. 2008), będących umiejętnościami koniecznymi do efektywnego funkcjonowania w sytuacjach zróżnicowanych kulturowo (zob. Soon Ang, Van Dyne 2008, s. 3). Wgląd w te procesy jest możliwy dzięki analizie opowieści ekspatów, polegającej na identyfikacji wiodących tematów, wyzwań, sytuacji krytycznych, które w przeszłości były okazją do kulturowego uczenia się.

W innym badaniu Anne-Marie Søderberg i Verner D. Worm (2011) pokazali, na podstawie wywiadów narracyjnych $\mathrm{z}$ chińskimi i zachodnimi menedżerami pracującymi w chińskich filiach pięciu przedsiębiorstw globalnych, że dotychczasowy, dominujący sposób patrzenia na współpracę między menedżerami z różnorodnym zapleczem kulturowym przez pryzmat różnych systemów wartości (co się często sprowadza do eksponowania opozycji kultur o wysokim vs. niskim kontekście lub kultur Wschodu vs. Zachodu, lub kultur kolektywistycznych vs. indywidualistycznych) wymaga rewizji. Na przykład nie da się sprowadzić tożsamości ekspatów do dobrze zdefiniowanej tożsamości narodowej albo zredukować ich obrazu do ludzi należących do kultur o jasno wytyczonych granicach, których zachowania można tym samym wpisać w jasno zdefiniowany wzorzec kulturowy, głęboko osadzony w określonej tradycji. Jest to niemożliwe z uwagi na często wielokulturowe doświadczenia ekspatów, którzy nierzadko studiują za granicą, odbywają zagraniczne podróże służbowe, za granicą zdobywają doświadczenie zawodowe i są co najmniej dwujęzyczni. Co więcej, tacy pracownicy są często świadomi własnej kultury i kultury kraju goszczącego oraz wykazują skłonność pokonywania różnic międzykulturowych przez adaptację.

Powyższe przykłady badań o charakterze eksploracyjnym pokazują potencjał podejścia narracyjnego w zgłębianiu komunikacji międzykulturowej. Ana- 
liza opowieści odsłania, w jaki sposób narratorzy - czy to ekspaci, czy lokalni uczestnicy komunikacji - konstruują tożsamość kulturową własną i innych ludzi, jak rozumieją pojęcie „kultury” i zjawisko kontaktu międzykulturowego, a także jak stosują to pojęcie do wyjaśniania międzykulturowych niepowodzeń komunikacyjnych i do nadawania sensu swoim międzykulturowym doświadczeniom. Poza tym narracje pogłębiają wiedzę na temat inteligencji kulturowej, zwłaszcza w wymiarach: (1) poznawczym, gdy narrator zdaje sobie sprawę z nowej wiedzy nabytej podczas doświadczenia kulturowego, (2) emocjonalnym, gdy relacjonowane w opowieści doświadczenie kulturowe wciąż wzbudza emocje u narratora, oraz (3) komunikacyjnym (metalingwalnym), gdy narrator przejawia zdolność zarówno werbalnego, jak i niewerbalnego działania celem stworzenia gruntu pod komunikację międzykulturową w następstwie kulturowego uczenia się (Søderberg, Worm 2011, s. 56).

Poza oczywistymi zaletami, jak np. zdobycie wglądu w doświadczenia międzykulturowe, uczestnictwo w wywiadzie narracyjnym jest aktywnością wyzwalającą u narratora refleksję nad jego międzykulturowymi doświadczeniami przez aktywację myślenia drugiego rzędu i stymulację metapoznania (Thomas i in. 2008; Søderberg, Worm 2011). Metapoznanie jest wskazywane jako decydujący czynnik w kulturowym uczeniu się (Gertsen, Søderberg 2010, s. 256), podczas gdy sama narracja jest procesem umożliwiającym skupienie uwagi narratora na doświadczeniu kulturowym z perspektywy czasu. Proces ten inicjuje refleksję nad międzykulturowymi doświadczeniami (często krytycznymi, wymagającymi z punktu widzenia narratora), ale też nad postrzeganiem siebie i aktorów opowieści, i pozwala mu uświadomić sobie, czego się nauczył z tych doświadczeń (jak rozwinęła się jego kompetencja międzykulturowa).

Co się zaś tyczy zastosowania praktycznego, metodę narracyjną można wykorzystać do stymulacji inteligencji międzykulturowej z korzyścią dla przedsiębiorstw globalnych przez np. wyznaczenie mentorów, którzy mieliby za zadanie wsłuchiwać się w opowieści ekspatów, albo przez organizowanie wewnętrznych sesji treningowych, w trakcie których ekspaci mogliby się dzielić własnymi historiami i tym samym mieć okazję je przemyśleć, zrozumieć, nadać im nowe znaczenie z korzyścią dla przyszłych interakcji międzykulturowych (Gertsen, Søderberg 2010).

\section{Podsumowanie}

Badacze międzykulturowi przejawiają tendencję do eksponowania różnic kulturowych, będących źródłem barier hamujących efektywność kontaktów międzykulturowych. Różnice kulturowe są najczęściej dyskutowane w pracach komparatystycznych na temat systemów wartości między kulturami Wschodu i Zachodu (Redding 1990; Jiing Lih Fahr, Bor-Shiuan Cheng 2000; Hao-Yi Chen, Henry Shang-Ren Kao 2009). Chociaż dotychczasowe badania sugerują wzmacnianie 
się różnic kulturowych między narodami, regionami czy grupami etnicznymi, które mogą prowadzić do problemów komunikacyjnych w zglobalizowanym biznesie (Ferraro 2002), to rosnąca liczba badań jakościowych - poświęconych zagadnieniu negocjacji i integracji znaczeń, a także sposobom budowania wspólnej płaszczyzny komunikacji i współpracy między osobami zróżnicowanymi kulturowo - pokazuje, że ludzie o różnych tożsamościach kulturowych nie zamieszkują odległych światów i niekoniecznie wyznają opozycyjne wartości.

Na potrzeby lepszego zrozumienia zjawiska komunikacji międzykulturowej w literaturze ukuto pojęcie „zasady interpunkcji” (ang. punctuation principle), zgodnie z którą ludzie reprezentujący różne kultury definiują swoje kolektywne tożsamości przez nakreślanie granic między poszczególnymi tożsamościami, szukając jednocześnie obszarów wspólnych (Klyukanov 2005, s. 20). Takie wspólne, obopólnie (przez uczestników komunikacji) akceptowane płaszczyzny mogą być podstawą kulturowej wymiany znaczeń, zaspokajającej psychologiczną potrzebę szacunku i uznania (zob. np. Gut i in. 2017). W tym kontekście efektywna komunikacja międzykulturowa powinna być postrzegana jako podstawa utrzymania satysfakcjonujących kontaktów w grupach wielokulturowych, a jej esencją jest negocjacja znaczeń. Udało się już wykazać, że skupianie się nie na różnicach, lecz na kulturowych podobieństwach, a także poszukiwanie wspólnej płaszczyzny negocjowania znaczeń stanowi cenny kapitał sprzyjający synergicznemu współdziałaniu grup kulturowych (zob. np. DiStefano, Maznevski 2000; Patel i in. 2011).

Badania narracyjne dają możliwość wglądu w proces komunikacji i współpracy międzykulturowej. Pozwalają przyjrzeć się nie tylko różnicom w doświadczeniach międzykulturowych, ale przede wszystkim podobieństwom - przy jednoczesnym poszukiwaniu tych obszarów, które mogą stanowić podstawę usprawnienia komunikacji i budowania międzykulturowego zaufania (Søderberg, Worm 2011, s. 58), jak również rozwoju inteligencji kulturowej i maksymalnego czerpania z różnorodności kulturowej w wielokulturowym miejscu pracy.

Tego rodzaju badania nie powinny się ograniczać do tworzenia międzykulturowych programów edukacyjnych, szkoleń kulturowych itp., ale przede wszystkim służyć środowisku pracy i międzynarodowym organizacjom w taki sposób, aby dać pracownikom i członkom tych organizacji możliwość ekspresji, wypowiedzenia własnych potrzeb, wyrażenia postaw i refleksji nad ich doświadczeniami międzykulturowymi.

W końcu badania narracyjne mogą prowadzić do zgłębienia rozumienia takich pojęć, jak „kompetencja międzykulturowa” czy „kulturowa inteligencja”, co z kolei mogłoby pomóc wielokulturowym organizacjom w procesie rekrutacji i szkoleniu inteligentnych kulturowo członków poprzez programy dotyczące przywództwa globalnego oraz programy treningowe i mentorskie (Gertsen, Søderberg 2010). 


\section{Bibliografia}

Abu-Rayya H.M., Abu-Rayya M.H. (2009). Acculturation, religious identity, and psychological well-being of among Palestinians in Israel. International Journal of Intercultural Relations, vol. 33(4), s. 291-300.

Ali A., Van der Zee K., Sanders G. (2003). Determinants of intercultural adjustment among expatriate spouses. International Journal of Intercultural Relations, vol. 27(5), s. 563-580.

Ambos T.C., Ambos B. (2009). The impact of distance on knowledge transfer effectiveness in multinational corporations. Journal of International Management, vol. 15(1), s. 1-14.

Ang Soon, Van Dyne L. (2008). Conceptualization of cultural intelligence: definition, distinctiveness, and nomological network. W: Ang Soon, Van Dyne L. (red.). Handbook of Cultural Intelligence: Theory, Measurement and Applications (s. 3-15). Armonk, NY: M.E. Sharpe.

Angouri J. (2013). The multilingual reality of the multinational workplace: Language policy and language use. Journal of Multilingual and Multicultural Development, vol. 34(6), s. 564-581.

Applegate J., Sypher H. (1988). A constructivist theory of communication and culture. W: Young Yun Kim, W.B. Gudykunst (red.). Theories of Intercultural Communication (s. 41-65). Newbury Park, CA: Sage.

Arasaratnam L.A. (2015). Research in intercultural communication: Reviewing the past decade. Journal of International and Intercultural Communication, vol. 8(4), s. 290-310.

Arasaratnam L.A., Banerjee S.C. (2011). Sensation seeking and intercultural communication competence: A model test. International Journal of Intercultural Relations, vol. 35(2), s. $226-233$.

Ariely G. (2011). Spheres of citizenship: The role of distinct perceived threats in legitimizing allocation of political, welfare and cultural rights in Israel. International Journal of Intercultural Relations, vol. 35(2), s. 213-222.

Baba M.L., Gluesing J., Ratner H., Wagner K.H. (2004). The contexts of knowing: Natural history of a globally distributed team. Journal of Organizational Behavior, vol. 25(5), s. 547-587.

Baba M.L., Gluesing J., Ratner H., Wagner K.H. (2004). The contexts of knowing: Natural history of a globally distributed team. Journal of Organizational Behavior, vol. 25(5), s. $547-587$.

Berry J.W. (1980). Acculturation as varieties of adaptation. W: A. Padilla (red.). Acculturation: Theory, Models and Some New Findings (s. 9-25). Boulder, CO: Westview Press.

Bird A., Osland J.S. (2006). Making Sense of Intercultural Collaboration. International Studies of Management and Organization, vol. 35(4), s. 115-32.

Björkman I., Tienari J., Vaara E. (2005). A learning perspective on sociocultural integration in cross-national mergers. W G.K. Stahl, M.E. Mendenhall (red.). Mergers and acquisitions: Managing culture and human resources (s. 155-175). Stanford, CA: Stanford University Press.

Bruner J. (2002). Making Stories: Law, Literature, Life. New York.

Burgoon J.K. (1995). Cross-cultural and intercultural applications of expectancy violations theory. W: R.L. Wiseman (red.). Intercultural Communication Theory (s. 194-214). Thousand Oaks, CA: Sage.

Byram M. (2009). Intercultural competence in foreign language education. W: D. Deardorff (red.). The Sage Handbook of Intercultural Competence (s. 321-332). Thousand Oaks, CA: Sage.

Cameron K.S., Dutton J.E., Quinn R.E. (2003). Positive Organizational Scholarship - Foundations of a New Discipline. San Francisco. 
Carbaugh D. (1990). Intercultural communication. W: D. Carbaugh (red.). Cultural Communication and Intercultural Contact (s. 151-175). Hillsdale, NJ: Lawrence Erlbaum.

Chen Hao-Yi, Kao Henry Shang-Ren (2009). Chinese paternalistic leadership and non-Chinese subordinates psychological health. International Journal of Human Resource Management, vol. 20(12), s. 2533-2546.

Cheng Hsin-I (2008). Space making: Chinese transnationalism on the U.S.-Mexican borderlands. Journal of International and Intercultural Communication, vol. 1(3), s. 244-263.

Child J., Faulkner D. (1998). Strategies of Cooperation: Managing Alliances, Networks, and Joint Ventures. Oxford.

Collie P., Kindon S., Liu J., Podsiadlowski A. (2010). Mindful identity negotiations: The acculturation of young Assyrian women in New Zealand. International Journal of Intercultural Relations, vol. 34(3), s. 208-220.

Cronen V., Chen V., Pearce W.B. (1988). Coordinated management of meaning. W: Young Yun Kim, W.B. Gudykunst (red.). Theories of Intercultural Communication (s. 66-98). Newbury Park, CA: Sage.

Czarniawska B., Gagliardi P. (red.) (2003). Narratives We Organize By. Amsterdam.

Den Brok P., Levy J., Wubbels T., Rodriguez M. (2003). Cultural influences on students' perceptions of videotaped lessons. International Journal of Intercultural Relations, vol. 27(3), s. $355-374$.

Dinsbach A.A., Feij J.A., de Vries R.E. (2007). The role of communication content in an ethnically diverse organization. International Journal of Intercultural Relations, vol. 31(6), s. 725-745.

DiStefano J.J., Maznevski M.L. (2000). Creating value in diverse teams in global management. Organizational Dynamics, vol. 29(1), 45-63.

Domurat A., Zajenkowska A., Grzegorzewska M. (2012). Confucian and Protestant work ethics among Polish and Korean employees and small business owners. Journal of Intercultural Communication, vol. 28 [http://www.immi.se/intercultural/nr28/domurat.htm; 5.02.2015].

Dougherty D.S., Kramer M.K., Hamlett S.R., Kurth T. (2009). Language convergence and meaning divergence: An examination of language and meaning for social-sexual behaviors in organizations. Communication Monographs, vol. 76, s. 20-46.

Dougherty D., Smith S., Mobley S. (2010). Language convergence and meaning divergence: A theory of intercultural communication. Journal of International and Intercultural Communication, vol. 3(2), s. 164-186.

Fahr Jiing Lih, Cheng Bor-Shiuan (2000). A cultural analysis of paternalistic leadership in Chinese organizations. W: Jiatao Tsui Li, S. Anne, E. Weldon (red.). Management and Organizations in the Chinese Context (s. 84-127). London: Macmillan.

Ferraro G.P. (2002). The Cultural Dimension of International Business (4th ed.). Upper Saddle River, NJ.

Fischer R. (2011). Cross-cultural training effects on cultural essentialism beliefs and cultural intelligence. International Journal of Intercultural Relations, vol. 35(6), s. 767-775.

Fitzsimmons S., Miska C., Stahl G.K. (2011). Multicultural employees: Global business' untapped resource. Organizational Dynamics, vol. 40, s. 199-206.

Ganesh S., Holmes P. (2011). Positioning intercultural dialogue - Theories, pragmatics, and an agenda. Journal of International and Intercultural Communication, vol. 4(2), s. 81-86.

Gareis E., Merkin R., Goldman J. (2011). Intercultural friendship: Linking communication variables and friendship success. Journal of Intercultural Communication Research, vol. 40(2), s. $153-171$.

Gertsen M.C., Søderberg A.-M. (2010). Expatriate stories about cultural encounters - A narrative approach to cultural learning processes in multinational companies. Scandinavian Journal of Management, vol. 26, s. 248-257. 
Gertsen M.C., Søderberg A.-M. (2011). Intercultural collaboration stories: On narrative inquiry and analysis as tools for research in international business. Journal of International Business Studies, 42(6), s. 787-804.

Gertsen M.C., Søderberg A., Zølner M. (red.) (2012). Global Collaboration: Intercultural Experiences and Learning. New York.

Goldstein S.B., Kim Randi I. (2006). Predictors of US college students' participation in study abroad programs: A longitudinal study. International Journal of Intercultural Relations, vol. 30(4), s. 507-521.

Gordon M.M. (1971). The nature of assimilation and the theory of the melting pot. W: E.P. Hollander, R.G. Hunt (red.). Current Perspectives in Social Psychology (s. 102-114). New York: Oxford University Press.

Gudykunst W.B. (1995). Anxiety/uncertainty management (AUM) theory. W: R.L. Wiseman (red.). Intercultural Communication Theory (s. 8-58). Thousand Oaks, CA: Sage.

Gudykunst W.B. (1997). Cultural variability in communication. Communication Research, vol. 24 , s. $327-348$.

Gudykunst W.B. (2005). Theories of intercultural communication I. China Media Research, vol. 1(1), s. 61-75.

Gut A., Wilczewski M., Gorbaniuk O. (2017). Cultural differences, stereotypes and communication needs in intercultural communication in a global multicultural environment. The employees' perspective. Journal of Intercultural Communication, vol. 43 [https://www.immi. se/intercultural/; 10.04.2017].

Hamilton G.G. (1994). Civilizations and Organization of Economies. W: N.J. Smelser, R. Swedberg (red.). The Handbook of Economic Sociology (s. 183-205). Princeton, NJ: Princeton University Press.

Hendrickson B., Rosen D., Aune R.K. (2011). An analysis of friendship networks, social connectedness, homesickness, and satisfaction levels of international students. International Journal of Intercultural Relations, vol. 35(3), s. 281-295.

Hofstede G. (1980). Culture's Consequences: International Differences in Work Related Values. Beverly Hills, CA.

Hofstede G. (1991). Cultures and Organizations: Software of the Mind. London.

Hofstede G. (2001). Culture's Consequences ( $2^{\text {nd }}$ ed.). Thousand Oaks, CA.

Holstein J., Gubrium J. (2008). Constructionist impulses in ethnographic fieldwork. W: J. Holstein, J. Gubrium (red.). Handbook of Constructionist Research (s. 373-395). New York: Guilford Press.

Holt J.L., DeVore C.J. (2005). Culture, gender, organizational role, and styles of conflict resolution: A meta-analysis. International Journal of Intercultural Relations, vol. 29(2), s. 165-196.

House R.J. i in. (2004). Culture, Leadership and Organization: A GLOBE Study of 62 Societies. Thousand Oaks.

Jibeen T., Khalid R. (2010). Predictors of psychological well-being of Pakistani immigrants in Toronto, Canada. International Journal of Intercultural Relations, vol. 34(5), s. 452-464.

Kalinowska-Andrian K. (2006). Positive Organizational Scholarship - nowy trend w nauce zarządzania. Zaproszenie do świata pozytywów. E-mentor, vol. 1(13) [http://www.e-mentor.edu.pl/artykul/index/numer/13/id/235; 16.06.2014].

Kassis-Henderson J. (2005). Language diversity in international management teams. International Studies of Management and Organization, vol. 35(1), s. 66-82.

Kim Min-Sun (1995). Toward a theory of conversational constraints: Focusing on individuallevel dimensions of culture. W: R.L. Wiseman (red.). Intercultural Communication Theory (s. 148-169). Thousand Oaks, CA: Sage.

Kim Young Yun (2001). Becoming Intercultural: An Integrative Theory of Communication and Cross-Cultural Adaptation. Thousand Oaks, CA. 
Kim Young Yun (2008). Intercultural personhood: Globalization and a way of being. International Journal of Intercultural Relations, vol. 32(4), s. 359-368.

Kincaid D.L. (1987). The convergence theory of communication, self-organization, and cultural evolution. W: D.L. Kincaid (red.). Communication Theory From Eastern and Western Perspectives (s. 209-221). New York: Academic Press.

Klak T., Martin P. (2003). Do university-sponsored international cultural events help students to appreciate „difference”? International Journal of Intercultural Relations, vol. 27(4), s. $445-465$.

Kluckhohn F.R., Strodtbeck F.L. (1961). Variations in Value Orientation. Evanston, IL.

Klyukanov I.E. (2005). Principles of Intercultural Communication. Boston, MA.

Komisarof A. (2009). Testing a modified interactive acculturation model in Japan: American-Japanese co-worker relations. International Journal of Intercultural Relations, vol. 33(5), s. 399-418.

Kumar R., Nti K.O. (2004). National cultural values and the evolution of process and outcome discrepancies in international strategic alliances. Journal of Applied Behavioral Science, vol. 40(3), s. 344-361.

Kurokawa Izumi, Yoshida Tomoko, Lewis C.H., Igarashi Remi, Kuradate Kenichi (2013). The plurilingual lounge: Creating new worldviews through social interaction. International Journal of Intercultural Relations, 37(1), s. 113-126.

Lee T.L., Fiske S.T. (2006). Not an outgroup, not yet an ingroup: Immigrants in Stereotype Content Model. International Journal of Intercultural Relations, vol. 30(6), s. 751-768.

Lin En-Yi (2008). Family and social influences on identity conflict in overseas Chinese. International Journal of Intercultural Relations, vol. 32(2), s. 130-141.

Lin Yi-Chun, Chen Angela Shin-Yih, Song Yi-Chen (2012). Does your intelligence help to survive in a foreign jungle? The effects of cultural intelligence and emotional intelligence on cross-cultural adjustment. International Journal of Intercultural Relations, vol. 36(4), s. 541-552.

Lissitsa S., Peres Y. (2011). Criteria of sociocultural adjustment: The case of Russian community in Israel since 1989. International Journal of Intercultural Relations, 35(2), s. 205-212.

Liu Shuang (2007). Living with others: Mapping the routes to acculturation in a multicultural society. International Journal of Intercultural Relations, 31(6), s. 761-778.

Liu Shuang (2011). Acting Australian and being Chinese: Integration of ethnic Chinese business people. International Journal of Intercultural Relations, vol. 35(4), s. 406-415.

Lough B.J. (2011). International volunteers' perceptions of intercultural competence. International Journal of Intercultural Relations, 35(4), s. 452-464.

Lücke G., Kostova T., Roth K. (2014). Multiculturalism from a cognitive perspective: Patterns and implications. Journal of International Business Studies, 45(2), s. 169-190.

Luijters K., van der Zee K.I., Otten S. (2008). Cultural diversity in organizations: Enhancing identification by valuing differences. International Journal of Intercultural Relations, 32(2), s. 154-163.

Lyttle A.D., Barker G.G., Cornwell T.L. (2011). Adept through adaptation: Third culture individuals' intercultural sensitivity. International Journal of Intercultural Relations, 35(5), s. 686-694.

Markus H.R., Mullally P., Kitayama S. (1997). Selfways: Diversity in modes of cultural participation. W: U. Neisser, D. Jopling (red.). The Conceptual Self in Context: Culture, Experience, Self-Understanding (s. 13-61). New York: Cambridge University Press.

Marschan R., Welch D.E., Welch L.S. (1997). Language: The forgotten factor in multinational management. European Management Journal, vol. 15(5), s. 591-598.

McFarlin D.B., Sweeney P.D. (2006). International Management. Strategic Opportunities and Cultural Challenges. Boston-New York. 
Meeusen C., de Vroome T., Hooghe M. (2013). How does education have an impact on ethnocentrism? A structural equation analysis of cognitive, occupational status and network mechanisms. International Journal of Intercultural Relations, 37(5), s. 507-522.

Merkin R.S. (2005). The influence of masculinity-femininity on cross-cultural facework. Journal of Intercultural Communication Research, 34(3/4), s. 267-289.

Merkin R.S. (2006). Uncertainty avoidance and facework: A test of Hofstede's model. International Journal of Intercultural Relations, 30(2), s. 213-228.

Mikułowski Pomorski J. (2007). Jak narody porozumiewają się ze sobą w komunikacji międzykulturowej i komunikowaniu medialnym. Kraków: Universitas.

Miller A.M., Sorokin O., Wang E., Feetham S., Choi M., Wilbur J. (2006). Acculturation, social alienation, and depressed mood in midlife women from the former Soviet Union. Research in Nursing and Health, vol. 9(2), s. 134-146.

Milstein T. (2005). Transformation abroad: Sojourning and the perceived enhancement of self-efficacy. International Journal of Intercultural Relations, 29(2), s. 217-238.

Mobley S.K., Smith S.E. (2010). Language convergence and meaning divergence: A theory of intercultural communication. Journal of International and Intercultural Communication, 3(2), s. 164-186.

Musacchio Adorisio A.L. (2015). A narrative lens for financial communication: Taking the „linguistic turn". Studies in Communication Sciences, vol. 15, s. 77-82.

Navas M., Garcia M.C., Sanchez J., Rojas A.J., Pumares P., Fernandez J.S. (2005). Relative acculturation extended model (RAEM): New contributions with regard to the study of acculturation. International Journal of Intercultural Relations, vol. 29(1), s. 21-37.

Nisbett R.E., Peng Kaiping, Choi Incheol, Norenzayan, A. (2001). Culture and systems of thought: Holistic vs analytic cognition. Psychological Review, vol. 108, s. 291-310.

Oetzel J.G. (1995). Intercultural small groups: An effective decision-making theory. W: R.L. Wiseman (red.). Intercultural Communication Theory (s. 247-270). Thousand Oaks, CA: Sage.

Oetzel J.G., McDermott V.M., Torres A., Sanchez C. (2012). The impact of individual differences and group diversity on group interaction climate and satisfaction: A test of the effective intercultural workgroup theory. Journal of International and Intercultural Communication, vol. 5(2), s. 144-167.

Padilla A.M. (1980). The role of cultural awareness and ethnic loyalty in acculturation. W: A.M. Padilla (red.). Acculturation: Theory, Models and Some New Findings (s. 47-84). Boulder, CO: Westview.

Park S.H., Ungson G.R. (1997). The effect of national culture, organizational complementarity, and economic motivation on joint venture dissolution. Academy of Management Journal, vol. 40(2), s. 279-307.

Patel F., Sooknanan P., Li Mingsheng (2011). Critical issues in intercultural communication. W: Intercultural Communication: Building a Global Community (s. 13-138). Thousand Oaks, CA: Sage Publications.

Pederson P.J. (2010). Assessing intercultural effectiveness outcomes in a year-long study abroad program. International Journal of Intercultural Relations, 34(1), s. 70-80.

Peltokorpi V. (2007). Intercultural communication patterns and tactics: Nordic expatriates in Japan. International Business Review, vol. 16(1), s. 68-82.

Peltokorpi V. (2008). Cross-cultural adjustment of expatriates in Japan. International Journal of Human Resource Management, vol. 19(9), s. 1588-1606.

Peltokorpi V. (2010). Intercultural communication in foreign subsidiaries: The influence of expatriates' language and cultural competencies. Scandinavian Journal of Management, vol. 26(2), s. 176-188.

Petrakis P.E. (2014). Culture, Growth and Economic Policy. Heidelberg. 
Pettigrew T.F., Christ O., Wagner U., Stellmacher J. (2007). Direct and indirect intergroup contact effects on prejudice: A normative interpretation. International Journal of Intercultural Relations, vol. 1(4), s. 411-425.

Philipsen G., Coutu L.M., Covarrubias P. (2005). Speech codes theory: Restatement, revisions, and response to criticisms. W: W.B. Gudykunst (red.). Theorizing About Intercultural Communication (s. 55-68). Thousand Oaks, CA: Sage.

Phuong-Mai Nguyen, Terlouw C., Pilot A. (2005). Cooperative learning vs Confucian heritage culture's collectivism: Confrontation to reveal some cultural conflicts and mismatch. Asia Europe Journal, vol. 3(3), s. 403-419.

Piekkari R. (2006). Language effects in multinational corporations: A review from an international human resource management perspective. W G.K. Stahl, I. Björkman (red.). Handbook of research in international human resource management (s. 536-550). Northampton, MA: Edward Elgar.

Piller I. (2007). Linguistics and intercultural communication. Language and Linguistic Compass, vol. 1/3, 208-226.

Plum E., Achen B., Dræby I., Jensen I. (2008). Cultural Intelligence - The Art of Leading Cultural Complexity. London.

Polkinghorne D.E. (1988). Narrative Knowing and the Human Sciences. Albany, NY.

Pratt M. (1998). To be or not to be? Central questions in organizational identification. W: D.A. Whetten, P.C. Godfrey (red.). Identity in Organizations (s. 171-207). Thousand Oaks, CA: Sage.

Prevot F., Meschi P.-X. (2006). Evolution of an international joint venture: The case of a French-Brazilian joint venture. Thunderbird International Business Review, vol. 48(3), s. 297-319.

Ramasubramanian S. (2010). Testing the cognitive-affective consistency model of intercultural attitudes: Do stereotypical perceptions influence prejudicial feelings? Journal of Intercultural Communication Research, s. 39(2), s. 105-121.

Ramasubramanian S. (2013). Intergroup contact, media exposure, and racial attitudes. Journal of Intercultural Communication Research, 42(1), s. 54-72.

Ratajczak M. (2006). Komunikacja międzykulturowa. Wybrane zagadnienia. W: M. Ratajczak (red.). Pomiędzy kulturami. Szkice z komunikacji międzykulturowej (s. 11-23). Wrocław: Wydawnictwo Uniwersytetu Wrocławskiego.

Redding S.G. (1990). The Spirit of Chinese Capitalism. Berlin.

Renzaho A.M.N., McCabe M., Sainsbury W.J. (2011). Parenting, role reversals and the preservation of cultural values among Arabic speaking migrant families in Melbourne, Australia. International Journal of Intercultural Relations, vol. 35(4), s. 416-424.

Riessman C. (1993). Narrative Analysis (Qualitative Research Methods Series 30). Newbury Park, CA.

Rivers D.J. (2011). Evaluating the self and the other: Imagined intercultural contact within a „native speaker” dependent foreign language context. International Journal of Intercultural Relations, s. 35(6), s. 842-852.

Rodriguez-Garcia J.-M., Wagner U. (2009). Learning to be prejudiced: A test of unidirectional and bidirectional models of parent-offspring socialization. International Journal of Intercultural Relations, s. 33(6), s. 516-523.

Ross L. (1977). The intuitive psychologist and his shortcomings: Distortions in the attribution process. W: L. Berkowitz (red.). Advances in Experimental Social Psychology (s. 174220). New York: Academic Press.

Roulston K. (2010). Considering quality in qualitative interviewing. Qualitative Research, vol. 10(2), s. 199-228.

Rozkwitalska M. (2011). Bariery w zarządzaniu międzykulturowym. Perspektywa filii zagranicznych korporacji transnarodowych. Warszawa. 
Sackmann S.A., Phillips M.E. (2004). Contextual influences on culture research: Shifting assumptions for new workplace realities. International Journal of Cross-Cultural Management, vol. 4(3), s. 370-390.

Safdar S., Calvez S., Lewis J.R. (2012). Multi-group analysis of the MIDA model: Acculturation of Indian and Russian immigrants to Canada. International Journal of Intercultural Relations, vol. 36(2), s. 200-212.

Saskia W. (2008). Identity mobilization practices of refugees: The case of Iraqis in the United States and the war in Iraq. Journal of International and Intercultural Communication, vol. 1(3), s. 202-220.

Schaafsma J. (2013). Through the lens of justice: Just world beliefs mediate relationships between perceived discrimination and subjective well-being. International Journal of Intercultural Relations, vol. 37(4), s. 450-458.

Schwartz S.H. (1992). Universals in the content and structure of values: Theoretical advances and empirical tests in 20 countries. W: M.P. Zanna (red.). Advances in Experimental Social Psychology (s. 1-65). San Diego.

Sheer V.C., Chen Ling (2003). Successful Sino-Western business negotiation: Participants' accounts of national and professional cultures. Journal of Business Communication, vol. 10(1), s. 50-85.

Shenkar O., Zeira Y. (1992). Role conflict and role ambiguity of chief executive officers in international joint ventures. Journal of International Business Studies, sino-Western business negotiation 23(1), s. 55-75.

Smith P.B., Peterson M.F., Schwartz S.H. (2002). Cultural values, sources of guidance, and their relevance to managerial behavior. Journal of Cross-Cultural Psychology, vol. 33(2), s. $188-208$.

Søderberg A.-M. (2006), Narrative interviewing and narrative analysis in a study of a cross-border merger. Management International Review, vol. 46(4), s. 397-416.

Søderberg A.-M., Worm V.D. (2011). Communication and collaboration in subsidiaries in China - Chinese and expatriate accounts. European Journal of Cross-Cultural Competence and Management, vol. 2(1), s. 54-76.

Stahl G.K., Maznevski M., Voigt A., Jonsen K. (2010). Unraveling the effects of cultural diversity in teams: A meta-analysis of research on multicultural work groups. Journal of International Business Studies, vol. 41, s. 690-709.

Stephan W.G., Stephan C.W. (2013). Designing intercultural education and training programs: An evidence-based approach. International Journal of Intercultural Relations, vol. 37(3), s. $277-286$.

Steuer R., Wood T. (2008). Storytellers and their discursive strategies in a post-acquisition process. Journal of Organizational Change Management, vol. 21(5), s. 574-588.

Stevens F.G., Plaut V.C., Sanchez-Burks J. (2008). Unlocking the benefits of diversity. All-inclusive multiculturalism and positive organizational change. Journal of Applied Behavioral Science, vol. 44, s. 116-133.

Suutari V., Mäkelä K. (2007). The career capital of managers with global careers. Journal of Managerial Psychology, vol. 22(7), s. 628-648.

Tamam E. (2010). Examining Chen and Starosta's model of intercultural sensitivity in a multiracial collectivistic country. Journal of Intercultural Communication Research, vol. 39(3), s. $173-183$.

ten Thije J.D., Maier R. (2012). Managing cultural and linguistic diversity in multiple organisational settings: Editorial. Journal of Multilingual and Multicultural Development, vol. 33(7), s. 629-641. 
Thomas D.C., Elron E., Stahl G., Ekelund B.Z., Ravlin E.C., Cerdin J.-L. i in. (2008). Cultural intelligence: Domain and assessment. International Journal of Cross Cultural Management, vol. 8(2), s. 123-143.

Ticehurst B., Downs C.W. (1999). Professional communication in Asia/Pacific organisations: A comparative study. Journal of Intercultural Communication, vol. 2 [http://www.immi.se/ intercultural/nr2/ticehurst.htm; 5.01.2015].

Ting-Toomey S. (2005). Identity negotiation perspective: A theoretical framework. W: W.B. Gudykunst (red.). Theorizing About Intercultural Communication (s. 211-234). Thousand Oaks, CA: Sage.

Tingvold L., Middelthon A.-L., Allen J., Hauff E. (2012). Parents and children only? Acculturation and the influence of extended family members among Vietnamese refugees. International Journal of Intercultural Relations, vol. 36(2), s. 260-270.

Triandis H.C. (1972). The Analysis of Subjective Culture. New York.

Trompenaars F. (1993). Riding the Waves of Culture: Understanding Diversity in Global Business. Chicago.

Van Marrewijk A. (2004). The management of strategic alliances: Cultural resistance. Comparing the cases of a Dutch telecom operator in the Netherlands Antilles and Indonesia. Culture and Organization, vol. 10(4), s. 303-314.

Vangen S., Winchester N. (2014). Managing cultural diversity in collaborations: A focus on management tensions. Public Management Review, vol. 16(5), s. 686-707.

Weick K.E., Sutcliffe K.M., Obstfeld D. (2005). Organizing and the process of sensemaking. Organization Science, vol. 16(4), s. 409-421.

Welch D.E., Welch L.S., Piekkari R. (2005). Speaking in Tongues: The Importance of Language in International Management Processes. International Studies of Management and Organization, vol. 35(1), s. 10-27.

Wilczewski M. (2015). The role of cultural diversity in business communication contacts. Lingwistyka Stosowana / Applied Linguistics / Angewandte Linguistik, vol. 13, s. 86-102.

Wilczewski M., Gut A., Gorbaniuk O. (2017). The impact of individualism-collectivism orientation and communal orientation on employees' attitudes toward intercultural communication: The case of Chinese employees in an MNC. Journal of Intercultural Communication, vol. 45 (w druku).

Yang Ruby Pi-Ju, Noels K.A., Saumure K.D. (2006). Multiple routes to cross-cultural adaptation for international students: Mapping the paths between self-construals, English language confidence, and adjustment. International Journal of Intercultural Relations, vol. 30(4), s. 487-506.

Yu Baohua, Shen Huizhong (2012). Predicting roles of linguistic confidence, integrative motivation and second language proficiency on cross-cultural adaptation. International Journal of Intercultural Relations, vol. 36(1), s. 72-82.

Zhang Qin (2010). Asian Americans beyond the model minority stereotype: The nerdy and the left out. Journal of International and Intercultural Communication, vol. 3(1), s. 20-37.

\section{STRESZCZENIE}

W artykule zaprezentowano przegląd badań z zakresu komunikacji międzykulturowej, opublikowanych w czasopismach naukowych w ostatniej dekadzie. Dodatkowo wprowadzono podejście jakościowe do badania kulturowych doświadczeń i procesów uczenia się w kontekście organizacyjnym, określane w literaturze jako badanie narracyjne. Proponujemy, by podejście narracyjne zostało wykorzystane w badaniach nad komunikacją międzykulturową, gdyż oferuje narzędzia dające dostęp do sposobów, w jakie uczestnicy komunikacji opowiadają o swo- 
ich międzykulturowych doświadczeniach, do refleksji na ich temat, więc metoda narracyjna umożliwia ich głębsze zrozumienie. Proces opowiadania historii daje narratorowi okazję (a) na nowo przeżyć (między)kulturowe doświadczenia, (b) nadać znaczenie tym doświadczeniom, a także (c) zrozumieć obecne i przeszłe potrzeby psychologiczne, sposoby postrzegania siebie i odmiennych kulturowo osób, jak również oczekiwania względem kontaktów z nimi. Analiza opowieści o ważnych z punktu widzenia narratora doświadczeniach kulturowych pozwala badaczowi uzyskać lepszy wgląd w proces komunikacji międzykulturowej, a narratorowi daje szansę zrozumienia przeszłych doświadczeń, konstruowania własnej tożsamości i wzmocnienia procesu kulturowego uczenia się.

Słowa kluczowe: komunikacja międzykulturowa/interkulturowa, konstruowanie tożsamości, kulturowe uczenie się, narracje, komunikacja w organizacjach 